\title{
Carbonized Waste Corrugated Paper Packaging Boxes as Low-Cost Adsorbent for Removing Aqueous Pb(II), Cd(II), Zn(II), and Methylene Blue
}

\author{
Zhuhong Ding ${ }^{1 *}$, Xuebin $\mathrm{Xu}^{1}$, Thihongnhung Phan ${ }^{1}$, Xin $\mathrm{Hu}^{2}$ \\ ${ }^{1}$ School of Environmental Science and Engineering, Nanjing Tech University, Nanjing, P.R. China \\ ${ }^{2}$ State Key Laboratory of Analytical Chemistry for Life Science, Center of Material Analysis and School \\ of Chemistry and Chemical Engineering, Nanjing University, Nanjing, P.R. China
}

Received: 28 September 2017

Accepted: 14 December 2017

\begin{abstract}
A common solid waste - corrugated-paper packaging boxes - was carbonized at 300,450 , and $600^{\circ} \mathrm{C}$ to develop low-cost adsorbents (biochars). The resulting adsorbents were characterized and their adsorption performances were evaluated by the batch sorption of aqueous $\mathrm{Pb}(\mathrm{II}), \mathrm{Zn}(\mathrm{II}), \mathrm{Cd}(\mathrm{II})$, and methylene blue (MB). The biochar obtained at $600^{\circ} \mathrm{C}$ exhibited larger specific surface area, higher mineral contents, and $\mathrm{pH}$ of zero point charge (pHPZC). Calcium carbonate, lead carbonate/basic, and zinc carbonate were observed in the metal-sorbed biochars by a power X-ray diffractometer (XRD). The biochar of higher pyrolysis temperature $\left(600^{\circ} \mathrm{C}\right)$ had high sorption capacity of aqueous $\mathrm{Pb}(\mathrm{II}), \mathrm{Zn}(\mathrm{II})$, and $\mathrm{Cd}(\mathrm{II})$ with the Langmuir maximum sorption capacity of 458,146 , and $10.7 \mathrm{mg} \mathrm{g}^{-1}$, respectively. The pseudo-second-order model gave a better fit for the kinetic data of $\mathrm{Pb}(\mathrm{II}), \mathrm{Zn}$ (II), $\mathrm{Cd}(\mathrm{II})$, and $\mathrm{MB}$ onto the biochar $\left(600^{\circ} \mathrm{C}\right)$. Moreover, the electrostatic attraction was the dominant mechanism for adsorption of $\mathrm{MB}$ while precipitation could be the main mechanisms for adsorption of $\mathrm{Pb}$ (II), $\mathrm{Zn}(\mathrm{II})$, and $\mathrm{Cd}(\mathrm{II})$. Therefore, carbonization can be an efficient and value-addition method for the recycling of waste corrugated paper packaging boxes and for the low-cost wastewater treatment.
\end{abstract}

Keywords: waste packaging box, recycling, heavy metals, dye, sorption

\section{Introduction}

Due to increasing public awareness on environmental issues, the recycling of solid waste, a kind of discarded resource, has received more and more attention recently.

*e-mail: dzhuhong@njtech.edu.cn

It has been reported that 66.8 percent of paper consumed in the United States was recovered for recycling in 2015 (paperrecycles.org). Generally, waste paper contains not only cellulose but also fillers (e.g., calcium carbonate or aluminosilicates) and organic/inorganic adhesives (e.g., corn starch or polyvinyl alcohol) to improve the their properties [1]. The traditional recycling of waste paper is made into paper-based packaging and other recycled papers (paperrecycles.org). In recent years, 
new value-added utilization of the waste paper has also been investigated as adsorbents [2], energy storage material [3], textiles [4], renewable fuel [5], and so on. Corrugated-paper is widely used for packaging or shipping and becomes a kind of common solid waste. The novel attempts on the recycling of waste corrugatedpaper packaging boxes may improve their economic and environmental interest.

Sorption is considered a removal method with easy operation and low cost widely used in wastewater treatment [6]. Although various types of sorbents have been developed and applied for water treatment during the past few decades, the development of novel and low-cost sorbents is still an important environmental research field. In recent years, carbon-based biochar, the carbonization of a variety of biomass and biomasslike materials under an oxygen-limited environment, has received much more attention because of its wide application such as carbon sequestration [7], soil improvement [8-9], and wastewater treatment [10-11]. Biochar has been validated as a renewable, low-cost and sustainable adsorbent for the removal of aqueous organic and inorganic contaminants [12-13]. However, the sorption performance of many pristine biochars derived from agricultural and forest biomass was relatively low [13]. Previous research confirms that the impregnation of minerals or metal oxides in biochar enhances significantly the sorption capacities of contaminants [14]. For example, Fe-impregnated biochar, prepared through a novel method that directly hydrolyzes iron salt onto hickory biochar was investigated for its performance as a lowcost arsenic (As) sorbent [15]. The mineral or metal ions' impregnation into the raw agricultural and forest biomass is a tedious step for the preparation of biochars due to its low adsorption capacities for mineral or metal ions. Waste paper is a subsistent mixture of organic matters (e.g., cellulose and/or inorganic adhesives) and mineral fillers (e.g., calcium carbonate and/or aluminosilicates) [1]. Therefore, the cost for the impregnation process can be ignored when the waste papers were carbonized. Our previous study shows that the carbonized waste-art-paper showed high sorption capacity of aqueous $\mathrm{Pb}$ (II) [16]. Therefore, the direct carbonization of waste paper may be a low-cost method for developing novel adsorbents.

In this study, waste-corrugated cardboard boxes were carbonized at temperatures of 300,450 , and $600^{\circ} \mathrm{C}$, and the basic physicochemical properties of the resultant biochars were characterized. Batch experiments were conducted to examine sorption behavior of heavy metals (e.g., $\mathrm{Pb}(\mathrm{II}), \mathrm{Cd}(\mathrm{II})$, and $\mathrm{Zn}(\mathrm{II})$ ), and organic dyes (e.g., methylene blue, or $\mathrm{MB}$ ) onto the pristine biochars. The objectives of this work were: 1) to prepare and characterize the adsorbents - biochars - from the waste corrugated paper packaging boxes and 2) to explore the sorption performance of the resultant biochars for heavy metals and organic dyes, respectively. The simple treatment of waste-corrugated cardboard boxes to obtain highly efficient sorbent may offer a new method for the recycling and reuse of waste paper.

\section{Experimental}

\section{Chemical Reagents}

All the chemical reagents used were of analytic grade and solutions were prepared using ultrapure water $(18.3 \mathrm{M} \Omega * \mathrm{~cm})$ from Milli-Q Advantage A10 (Millipore, USA). Cadmium chloride $\left(\mathrm{CdCl}_{2} \cdot 2.5 \mathrm{H}_{2} \mathrm{O}\right)$, lead nitrate $\left(\mathrm{Pb}\left(\mathrm{NO}_{3}\right)_{2}\right)$, zinc nitrate $\left(\mathrm{Zn}\left(\mathrm{NO}_{3}\right)_{2} \cdot 6 \mathrm{H}_{2} \mathrm{O}\right)$, potassium nitrate $\left(\mathrm{KNO}_{3}\right)$, nitric acid $\left(\mathrm{HNO}_{3}\right)$, sodium hydroxide $(\mathrm{NaOH})$, and methylene blue $\left(\mathrm{C}_{16} \mathrm{H}_{18} \mathrm{ClN}_{3} \mathrm{~S}\right)(\mathrm{MB})$ were purchased from Sinopharm Chemical Reagent Co., Ltd. All the lab ware was soaked in dilute nitric acid at least overnight, thoroughly flushed with tap water, and then with ultrapure water.

\section{Preparation of Biochars}

Waste corrugated-paper packaging boxes were collected from our lab and a local supermarket. They were then snipped to fragments (about $2 \times 5 \mathrm{~cm}$ ) using scissors. This feedstock was pyrolyzed under oxygen-limited condition in a muffle furnace (CIMO, $\mathrm{SX}_{2}-4-10$, China) at peak temperature of 300 , 450 , and $600^{\circ} \mathrm{C}$. The temperature was raised at a rate of $10^{\circ} \mathrm{C} \mathrm{m^{-1 }}$ and held at the peak for $2 \mathrm{~h}$. The obtained biochars were sieved with 18-mesh and 60-mesh nylon sieves to obtain $0.250-1.00 \mathrm{~mm}$ fraction, marked as CB300, CB450, and CB600, respectively, and stored for further investigation.

\section{Characterization of Biochars}

Contents of carbon $(\mathrm{C})$, hydrogen $(\mathrm{H})$, and nitrogen (N) in the pristine biochar samples were determined using a CHN Elemental Analyzer (Carlo-Erba NA-1500). Mineral elements were analyzed with an ICP-OES (PerkinElmer, Optima 5300DV, USA) after ashing at $360^{\circ} \mathrm{C}$ and acid dissolution. Specific surface areas of the biochar samples were measured with a surface area analyzer (BET, ASAP20, Micromeritics, Ltd., USA) using $\mathrm{N}_{2}$ adsorption methods. Points of zero charge $\left(\mathrm{pH}_{\mathrm{pzc}}\right)$ were measured by modified $\mathrm{pH}$ drift method as the previous literature [17]. Infrared spectrogram of the pristine biochars was measured by Fourier-transformed infrared spectroscopy (FTIR) (NEXUS870, NICOLET, USA) for characterizing the functional groups present in the pristine biochars. A powder X-ray diffractometer (XRD) was used to identify the crystal structure in the pristine and the heavy metal-adsorbed biochars.

\section{Batch Sorption Experiments}

Sorption isotherms of $\mathrm{Cd}(\mathrm{II}), \mathrm{Pb}(\mathrm{II}), \mathrm{Zn}(\mathrm{II})$, and $\mathrm{MB}$ onto the biochars were studied at room temperature $\left(22 \pm 2^{\circ} \mathrm{C}\right)$ by adding $0.05 \mathrm{~g}$ biochar sample to a $50 \mathrm{~mL}$ plastic centrifuge tube containing $25 \mathrm{~mL}$ solution of $\mathrm{Cd}(\mathrm{II}), \mathrm{Pb}(\mathrm{II}), \mathrm{Zn}(\mathrm{II})$, or $\mathrm{MB}$, respectively. According to our pre-experiments, initial concentrations of $\mathrm{Cd}(\mathrm{II})$ 
ranged from 1 to $50 \mathrm{mg} \mathrm{L}^{-1}$. Initial concentrations of $\mathrm{Pb}$ (II) ranged from 20 to $300 \mathrm{mg} \mathrm{L}^{-1}$ for $\mathrm{CB} 300,50$ to $1,000 \mathrm{mg} \mathrm{L}^{-1}$ for $\mathrm{CB} 450$, and 200 to $1,500 \mathrm{mg} \mathrm{L}^{-1}$ for CB600, respectively. Initial concentrations of $\mathrm{Zn}$ (II) ranged from 5 to $80 \mathrm{mg} \mathrm{L}^{-1}$ for CB300, 20 to $300 \mathrm{mg} \mathrm{L}^{-1}$ for CB450, and 50 to $500 \mathrm{mg} \mathrm{L}^{-1}$ for CB600, respectively. $\mathrm{MB}$ initial concentration ranged from 5 to $150 \mathrm{mg} \cdot \mathrm{L}^{-1}$. Initial $\mathrm{pH}$ of $\mathrm{Pb}(\mathrm{II}) / \mathrm{Cd}(\mathrm{II}) / \mathrm{Zn}(\mathrm{II})$ solution was measured using a $\mathrm{pH}$ meter. The tubes were shaken in a rotating disk for $24 \mathrm{~h}$ to arrive at the sorption equilibrium. After centrifugation and filtration, final $\mathrm{pH}$ values of the filtrated solutions were determined by the $\mathrm{pH}$ meter. Concentrations of heavy metal ions $\left(\mathrm{Cd}^{2+}, \mathrm{Pb}^{2+}\right.$ and $\left.\mathrm{Zn}^{2+}\right)$ in the filtrates were determined by using an ICP-OES (PerkinElmer, Optima 5300DV, USA). Equilibrium concentration of $\mathrm{MB}$ was measure using an ultraviolet spectrophotometer (PHILES, T-6, China) at $663 \mathrm{~nm}$ and $\mathrm{pH} 7.0$ buffer systems. The amount of $\mathrm{Cd}(\mathrm{II})$, $\mathrm{Pb}(\mathrm{II}), \mathrm{Zn}(\mathrm{II})$, and $\mathrm{MB}$ sorbed was calculated using $q_{e}=\left[\left(C_{0}-C_{e}\right) V\right] / m$, where $C_{0}$ and $C_{e}$ are the initial and equilibrium concentrations of metal ions or $\mathrm{MB}\left(\mathrm{mg} \mathrm{L}^{-1}\right)$, respectively; $V$ is the volume of the solution $(\mathrm{L})$; and $\mathrm{m}$ is the mass of biochar $(\mathrm{g})$.

An appropriate concentration of $\mathrm{Cd}(\mathrm{II}), \mathrm{Pb}(\mathrm{II}), \mathrm{Zn}(\mathrm{II})$, or $\mathrm{MB}$ for the kinetic sorption experiments were selected according to their sorption isotherms to avoid full adsorption at the beginning of the experiments or high residual concentrations. The kinetic sorption experiments were also carried out at room temperature $\left(22 \pm 2^{\circ} \mathrm{C}\right)$ by adding $0.05 \mathrm{~g}$ biochar sample to $50 \mathrm{~mL}$ plastic centrifuge tube containing $25 \mathrm{~mL}$ of $\mathrm{Cd}(\mathrm{II}), \mathrm{Pb}(\mathrm{II}), \mathrm{Zn}(\mathrm{II})$, or MB. The initial concentrations of $\mathrm{Cd}(\mathrm{II}), \mathrm{Pb}(\mathrm{II}), \mathrm{Zn}(\mathrm{II})$, and $\mathrm{MB}$ were $30 \mathrm{mg} \mathrm{L}^{-1}, 1,000 \mathrm{mg} \cdot \mathrm{L}^{-1}, 500 \mathrm{mg} \mathrm{L}{ }^{-1}$, and $50 \mathrm{mg} \mathrm{L}^{-1}$, respectively. Initial solution $\mathrm{pH}$ was set at $5.0 \pm 0.2$ for $\mathrm{Cd}(\mathrm{II}), \mathrm{Pb}(\mathrm{II})$, and $\mathrm{Zn}(\mathrm{II})$, and $6.5 \pm 0.2$ for MB solution adjusted using $0.01 \mathrm{M} \mathrm{NaOH}$ or $\mathrm{HNO}_{3}$ and measured using the $\mathrm{pH}$ meter. Centrifuge tubes were sealed and agitated in a rotary shaker. At the end time of $1 \mathrm{~min}, 5 \mathrm{~min}, 10 \mathrm{~min}, 20 \mathrm{~min}, 30 \mathrm{~min}, 1 \mathrm{~h}, 2 \mathrm{~h}, 4 \mathrm{~h}, 8 \mathrm{~h}$, $16 \mathrm{~h}$, and $24 \mathrm{~h}$, the mixture was immediately centrifuged at $4,000 \mathrm{rpm}$ and filtered through $0.45-\mu \mathrm{m}$ pore size nylon membranes. The amount of $\mathrm{Cd}(\mathrm{II}), \mathrm{Pb}(\mathrm{II}), \mathrm{Zn}$ (II), or MB sorbed was calculated using $q_{t}=\left[\left(C_{0}-C\right) \mathrm{V}\right] / \mathrm{m}$, where $C_{t}$ is the concentrations of heavy metals or MB $\left(\mathrm{mg} \mathrm{L}^{-1}\right)$ at time of $t$.

\section{Recovery of Adsorbed Heavy Metals}

Acid-extraction experiments were carried out at room temperature $\left(22 \pm 2^{\circ} \mathrm{C}\right)$ to recover heavy metal ions from the post-sorption (heavy metal-laden) biochars. In order to obtain heavy metal-laden biochars, $0.05 \mathrm{~g}$ biochar was mixed with $25 \mathrm{~mL}$ heavy metal solution of $20 \mathrm{mg} \mathrm{L}^{-1}$ containing Cd(II) for CB300 and CB450, and $50 \mathrm{mg} \mathrm{L}^{-1}$ for CB600; $\mathrm{Pb}$ (II) of $50 \mathrm{mg} \mathrm{L}^{-1}$ for CB300, $500 \mathrm{mg} \mathrm{L}^{-1}$ for $\mathrm{CB} 450$, and 1,200 $\mathrm{mg} \mathrm{L}^{-1}$ for CB600; $\mathrm{Zn}$ (II) of $50 \mathrm{mg} \mathrm{L}^{-1}$ for CB300, and $500 \mathrm{mg} \mathrm{L}^{-1}$ for CB450 and CB600. The mixed solution was shaken for $24 \mathrm{~h}$ in a rotary shaker. After centrifugation and filtration, the residue was washed using deionized (DI) water 3 times and dried at $70^{\circ} \mathrm{C}$ in a drying oven (CIMO, DHG-903385-III, China) for $12 \mathrm{~h}$. Each post-sorption biochar sample was soaked in $3 \mathrm{~mL} 1.0 \mathrm{M} \mathrm{HNO}_{3}$ solution for $1 \mathrm{~h}$. The $\mathrm{Cd}(\mathrm{II}), \mathrm{Pb}(\mathrm{II})$, and $\mathrm{Zn}(\mathrm{II})$ concentrations in the leaching solution were measured by using ICP-OES. The desorption rate of heavy metal was calculated using $D(\%)=C_{d} \times \mathrm{V} \times 100 / q_{e}$, where $D$ is the desorption rate (\%); $C_{d}$ is the concentration of $\mathrm{Cd}(\mathrm{II}), \mathrm{Pb}(\mathrm{II})$, or $\mathrm{Zn}(\mathrm{II})$ in the leaching agent $\left(\mathrm{mg} \mathrm{L}^{-1}\right)$; $\mathrm{V}$ is the volume of $1.0 \mathrm{M} \mathrm{HNO}_{3}$ solution (L); and $q_{e}$ is the equilibrium adsorption capacity $\left(\mathrm{mg} \mathrm{g}^{-1}\right)$.

\section{Results and Discussion}

\section{Characterization of Biochars}

\section{Basic Properties of the Pristine Biochars}

The yields of waste corrugated-paper biochars at 300,450 , and $600^{\circ} \mathrm{C}$ were $48.1 \%, 30.1 \%$, and $26.7 \%$, respectively (Table 1), which were consistent with previous reports about decreasing yield with the

Table 1. Yield (\%), ash and elemental contents (\%), pore volume $\left(\mathrm{cm}^{3} \mathrm{~g}^{-1}\right)$, pore size $(\mathrm{nm})$, and surface area $\left(\mathrm{m}^{2} \mathrm{~g}^{-1}\right)$ of the pristine biochars.

\begin{tabular}{|c|c|c|c|c|c|c|c|}
\hline & Yield & $\mathrm{C}$ & $\mathrm{H}$ & $\mathrm{O}^{\mathrm{a}}$ & $\mathrm{N}$ & $\mathrm{H} / \mathrm{C}$ & $(\mathrm{N}+\mathrm{O}) / \mathrm{C}$ \\
\hline CB300 & 48.1 & 49.6 & 4.60 & 29.1 & 0.25 & 1.113 & 0.444 \\
\hline CB450 & 30.1 & 55.9 & 2.66 & 8.16 & 0.080 & 0.571 & 0.111 \\
\hline \multirow[t]{2}{*}{ CB600 } & 26.7 & 60.0 & 1.75 & 0.94 & 0.31 & 0.350 & 0.0162 \\
\hline & Ash & $\mathrm{Ca}$ & $\mathrm{Mg}$ & $\mathrm{Al}$ & Surface area $^{b}$ & Pore volume ${ }^{c}$ & Pore size $^{\mathrm{d}}$ \\
\hline CB300 & 16.5 & 1.78 & 0.169 & 0.955 & $3.47 / 1.32$ & $0.0158 / 0.0147$ & $18.2 / 44.6$ \\
\hline CB450 & 33.2 & 4.90 & 0.522 & 1.99 & $27.5 / 15.1$ & $0.0338 / 0.0285$ & $4.91 / 7.52$ \\
\hline CB600 & 37.0 & 4.11 & 0.413 & 2.40 & $270 / 65.4$ & $0.158 / 0.0621$ & $2.34 / 3.80$ \\
\hline
\end{tabular}

${ }^{\mathrm{a}}$ Calculated by mass difference between the total mass and the summation of $\mathrm{CHN}$ and ash of a sample, ${ }^{\mathrm{b}} \mathrm{BET} / \mathrm{BJH}$, ${ }^{\mathrm{c}} \mathrm{Total} / \mathrm{BJH}$, ${ }^{\mathrm{d}}$ Ave/BJH 


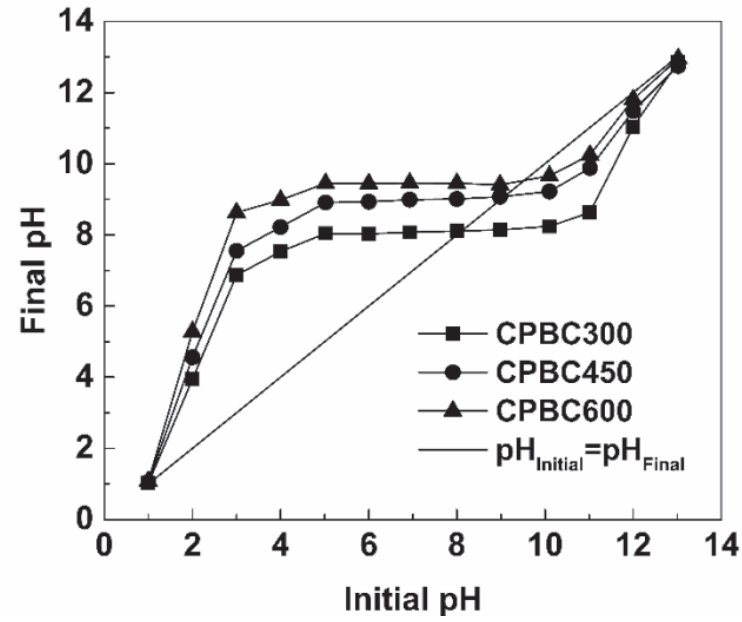

Fig. 1. $\mathrm{pH}_{\mathrm{PZC}}$ of the resultant biochars.

increasing pyrolysis temperature [13]. CHN element contents and ash content of the pristine biochars were also shown in Table 1. In general, the $\mathrm{C}$ and ash content of the pristine biochar increased with the increasing pyrolysis temperature, while $\mathrm{O}$ and $\mathrm{H}$ contents inversely decreased. This indicated that the pristine biochar carbonized at high temperature had higher contents of graphite carbon and ash. For example, CB600 showed the highest contents of $\mathrm{C}(60.0 \%)$ and ash $(37.0 \%)$. Atomic ratio of $\mathrm{H} / \mathrm{C}$ decreased from 1.11 to 0.35 , suggesting the strong carbonization and high aromaticity of the pristine biochars at high pyrolysis temperature [18-19]. The atomic ratio of $(\mathrm{N}+\mathrm{O}) / \mathrm{C}$ also decreased from 0.447 to 0.017 , reflecting a decreased polar-group content with the increasing pyrolysis temperature. The dominant mineral elements in the pristine biochars were $\mathrm{Ca}, \mathrm{Al}$, and $\mathrm{Mg}$. The $\mathrm{Ca}, \mathrm{Al}$, and $\mathrm{Mg}$ contents in $\mathrm{CB} 450$ and CB600 were obviously higher than that in CB300, which meant different mineral contents due to high pyrolysis temperature and low pyrolysis temperature.

$\mathrm{pH}_{\mathrm{pzc}}$ is an important indicator of the net surface charge and preference for ionic species of a sorbent.

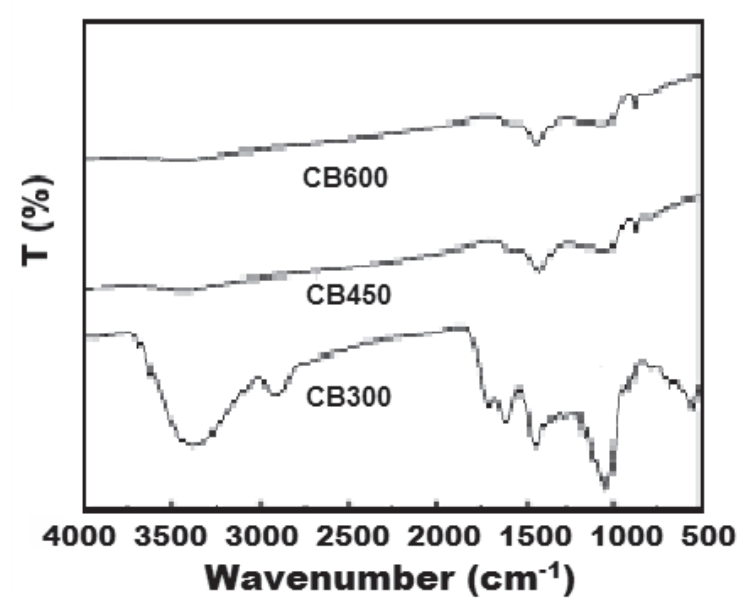

Fig. 2. FT-IR spectra of the resultant biochars.
The $\mathrm{pH}_{\mathrm{pzc}}$ curves of the pristine biochars are shown in Fig. 1. Obviously, the $\mathrm{pH}_{\mathrm{pzc}}$ values of three pristine biochars were quite similar, ranging from 8.0-9.5. The $\mathrm{pH}_{\mathrm{pzc}}$ values of the pristine biochars increased with the increasing pyrolysis temperature. Solution $\mathrm{pH}$ lower than $\mathrm{pH}_{\mathrm{pzc}}$ means positive surface charges of the resultant biochars, while the opposite result shows negative surface charges, which is easy to adsorb cations [20].

The The BET and BJH surface areas were listed in Table 1. The BET and BJH surface area aggrandized with the increase of pyrolysis temperature. The total and BJH pore volume also have the same variation trend. However, the average and BJH pore size decrease with the increasing pyrolysis temperature. This was similar to a recent report [13].

\section{FTIR Spectra of the Pristine Biochars}

FT-IR spectra of the pristine biochars are shown in Fig. 2. The broadband peak at 3,000 to $3,700 \mathrm{~cm}^{-1}$ (O-H stretching vibrations of hydrogen bonded hydroxyl groups) and serial peaks at 1,600 to $1,800 \mathrm{~cm}^{-1}(\mathrm{C}=\mathrm{O}$ stretching vibrations) in the pristine biochars became weaken at high pyrolysis temperature, which was indicative of a decrease of oxygen-containing functional group (similar to the result of element content). The infrared absorption band around $1,425 \mathrm{~cm}^{-1}$ was assigned to the stretching vibration band of $\mathrm{CO}_{3}^{2-}[21]$, and the peak at $1,000 \mathrm{~cm}^{-1}$ in $\mathrm{CB} 300$ was attributed to the stretching vibration band of $\mathrm{C}-\mathrm{O}$. With the increasing pyrolysis temperature the peaks were reduced (Fig. 1), suggesting the breakdown of the functional groups due to high pyrolysis temperature.

\section{XRD Spectra of the Pristine Biochars and Heavy Metal-Sorbed Biochars}

The XRD spectra of the pristine biochars are shown in Fig. 3a. The patterns show that there was an obvious change of the components in the pristine biochars under different pyrolysis temperatures. The strong peak corresponding to calcium carbonate $\left(\mathrm{CaCO}_{3}, \mathrm{PDF} \# 05-0586\right)$ observed at $29.38^{\circ}(d=3.04 \AA)$ in CB600 was stronger than those in CB300 and CB450, which indicated that high pyrolysis temperature could lead to the increasing content of $\mathrm{CaCO}_{3}$ in the pristine biochars, and was consistent with the previous reports [22]. Otherwise, a relatively weak peak at $9.40^{\circ}$ $(d=9.401 \AA)$ in all 3 pristine biochars was attributed to talcum $\left(\mathrm{Mg}_{3} \mathrm{Si}_{4} \mathrm{O}_{10}(\mathrm{OH})_{2}, \mathrm{PDF} \# 13-0558\right)$. However, the weak peak at $12.34^{\circ}(d=7.17 \AA)$ corresponding to kaolinite $\left(\mathrm{Al}_{2} \mathrm{Si}_{2} \mathrm{O}_{5}(\mathrm{OH})_{4}\right)$ was only observed in $\mathrm{CB} 300$ and CB450. In addition, the quartz peak at $26.62^{\circ}$ $(d=3.35 \AA)$ was only observed in CB450. This result suggested that the main mineral in waste corrugatedpaper biochars were calcium carbonate and a little clay mineral.

The XRD spectra of heavy metal-sorbed biochars (CB600-Pb, CB600-Zn, and CB600-Cd) are shown in Fig. $3 \mathrm{~b}$ as a series of new strong peaks that could be 

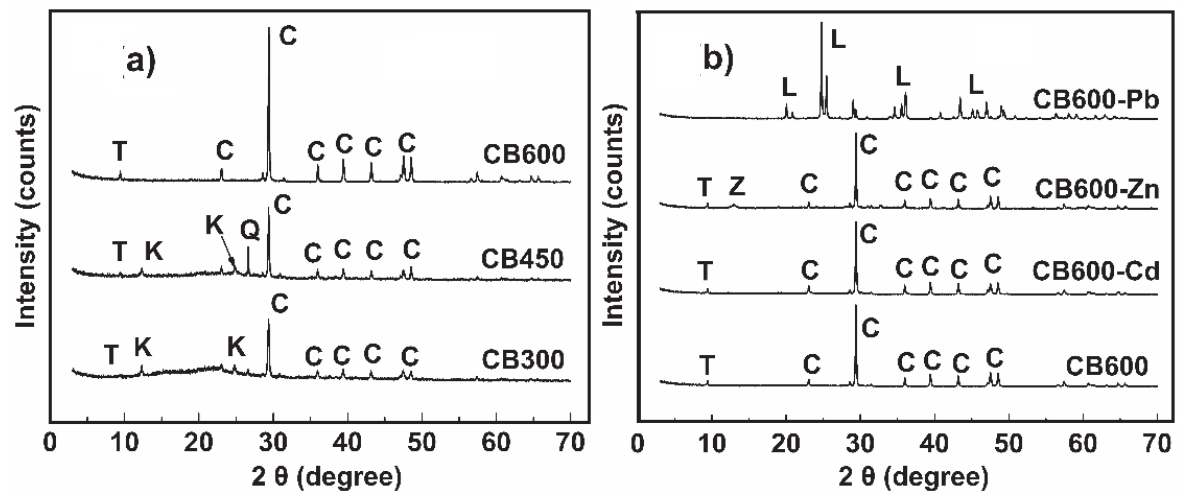

Fig. 3. XRD spectra of the pristine biochars a) and metal-ladened biochars b) (C: calcium carbonate, K: kaolinite, T: talcum, Q: quartz, $\mathrm{L}$ : lead carbonate, Z: basic zinc carbonate)

distinctly observed in $\mathrm{Pb}$-sorbed biochar (CB600-Pb). A strong peak at $24.78^{\circ}(d=3.59 \AA)$ and a weak peak $29.04^{\circ}(d=3.07 \AA)$ were identified as lead carbonate $\left(\mathrm{PbCO}_{3}\right)$, and a relatively weak peak at $36.1^{\circ}(d=2.49$ $\AA$ ) was attributed to basic lead carbonate $\left[\mathrm{Pb}_{2} \mathrm{CO}_{3}(\mathrm{OH})_{2}\right]$ [21]. In addition, the intensity of the calcite peak was reduced dramatically after the $\mathrm{Pb}(\mathrm{II})$ sorption. In $\mathrm{Zn}$ sorbed biochar $(\mathrm{CB} 600-\mathrm{Zn})$, a new and weak peak at $12.90^{\circ}(d=6.86 \AA)$ were identified as basic zinc carbonate $\left[\mathrm{Zn}_{2}(\mathrm{OH})_{2} \mathrm{CO}_{3}\right]$. However, no obvious new peak appeared in Cd-sorbed biochar, which may be due to the relatively low content of $\mathrm{Cd}$ sorbed that could not be detected by XRD. These results confirmed that the removal of $\mathrm{Pb}$ (II) and $\mathrm{Zn}$ (II) by the waste corrugated-paper biochar was mainly controlled by the precipitation mechanism through the reaction between calcite with $\mathrm{Pb}$ (II) and $\mathrm{Zn}(\mathrm{II})$.

\section{Sorption Isotherms}

The sorption isotherms are shown in Fig. 4. The sorption amount of the metal ions $(\mathrm{Pb}$ (II), $\mathrm{Zn}(\mathrm{II})$, and $\mathrm{Cd}(\mathrm{II})$ ) onto the pristine biochars increased rapidly, and then arrived at a platform with the increasing equilibrium concentrations of $\mathrm{Pb}(\mathrm{II}), \mathrm{Zn}(\mathrm{II})$, or $\mathrm{Cd}(\mathrm{II})$ (Fig. 4). Fig. 4 shows that the equilibrium adsorption capacities for $\mathrm{Pb}$ (II) were in the order of $\mathrm{CB} 600>\mathrm{CB} 450>\mathrm{CB} 300$ and the maximum equilibrium adsorption capacities of CB600 were about 50 times higher than that of CB300. Therefore, the pyrolysis temperature had significant influence on the maximum equilibrium adsorption capacities of waste corrugated-paper biochars, which was consistent with the results of biochars derived from other biomass feedstock [23-24]. $\mathrm{Zn}$ (II) and $\mathrm{Cd}(\mathrm{II})$ showed the similar adsorption processing as $\mathrm{Pb}(\mathrm{II})$
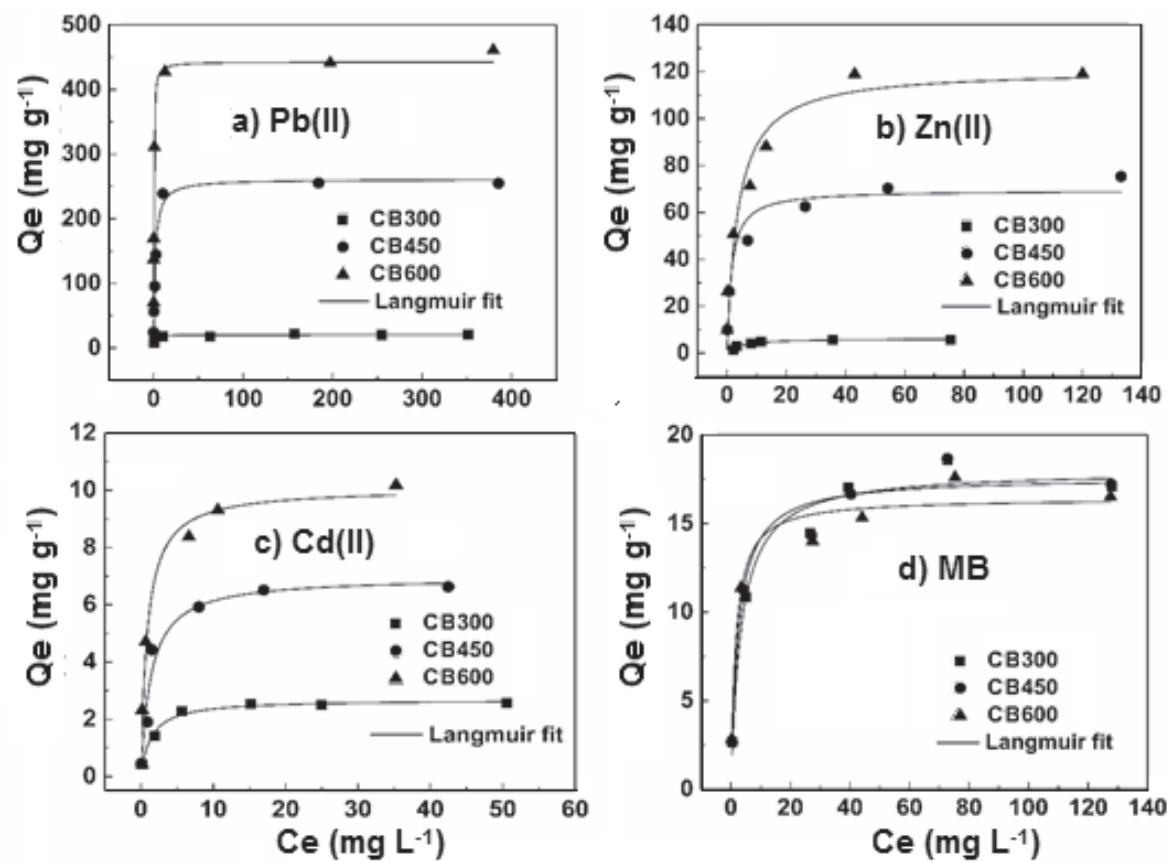

Fig. 4. Sorption isotherms of $\mathrm{Pb}(\mathrm{II}) \mathrm{a}), \mathrm{Zn}(\mathrm{II}) \mathrm{b}$ ), $\mathrm{Cd}(\mathrm{II}) \mathrm{c}$ ), and methylene blue d) onto biochars. 
Table 2. Isotherm model parameters for $\mathrm{Pb}(\mathrm{II}), \mathrm{Zn}(\mathrm{II}), \mathrm{Cd}(\mathrm{II})$, and $\mathrm{MB}$ sorption onto the tested biochars.

\begin{tabular}{|c|c|c|c|c|c|c|c|}
\hline \multirow{2}{*}{ Adsorbates } & \multirow{2}{*}{ Adsorbents } & \multicolumn{3}{|c|}{$C_{e} / q_{e}=C_{e} / q_{m}+1 /\left(K_{L} \times q_{m}\right)$ Langmuir model } & \multicolumn{3}{|c|}{$\lg q_{m}=\lg K_{F}+(1 / n) \lg C_{e}$ Freundlich model } \\
\hline & & $q_{m}$ & $K_{L}$ & $R^{2}$ & $K_{F}$ & $n$ & $R^{2}$ \\
\hline \multirow{3}{*}{$\mathrm{Pb}(\mathrm{II})$} & CB300 & 15.9 & 0.042 & 0.978 & 7.21 & 8.79 & 0.876 \\
\hline & CB450 & 256 & 0.889 & 0.999 & 83.1 & 4.10 & 0.874 \\
\hline & CB600 & 458 & 1.06 & 0.999 & 208 & 5.86 & 0.772 \\
\hline \multirow{3}{*}{$\mathrm{Zn}(\mathrm{II})$} & CB300 & 6.09 & 0.240 & 0.997 & 1.64 & 2.92 & 0.738 \\
\hline & CB450 & 76.2 & 0.333 & 0.998 & 24.2 & 3.70 & 0.949 \\
\hline & CB600 & 146 & 0.194 & 0.997 & 35.5 & 2.87 & 0.980 \\
\hline \multirow{3}{*}{$\mathrm{Cd}(\mathrm{II})$} & $\mathrm{CB} 300$ & 2.61 & 1.02 & 0.999 & 0.958 & 3.11 & 0.872 \\
\hline & CB450 & 6.86 & 0.769 & 0.999 & 2.01 & 2.34 & 0.869 \\
\hline & CB600 & 10.7 & 0.572 & 0.993 & 2.94 & 2.20 & 0.717 \\
\hline \multirow{3}{*}{ MB } & CB300 & 17.8 & 0.376 & 0.995 & 4.53 & 3.02 & 0.905 \\
\hline & CB450 & 17.9 & 0.375 & 0.995 & 4.87 & 3.19 & 0.894 \\
\hline & CB600 & 17.1 & 0.372 & 0.996 & 5.16 & 3.51 & 0.868 \\
\hline
\end{tabular}

$\mathrm{q}_{m}$ : maximum adsorption capacity $\left(\mathrm{mg} \mathrm{g}^{-1}\right), K_{L}$ : Langmuir constant $\left(\mathrm{L} \mathrm{mg}^{-1}\right), K_{F}$ : affinity coefficient related to the bonding energy $\left(\mathrm{mg}^{(1-1 / 1)} \mathrm{L}^{1 / n} \mathrm{~g}^{-1}\right), n$ : the heterogeneity factor representing bond distribution

(Fig. 4), and the equilibrium adsorption capacities also increased with the increasing pyrolysis temperature (Fig. 4). Therefore, it can be concluded that the pyrolysis temperatures were the important parameters for the adsorption performance of the pristine biochars. Sorption isotherms of $\mathrm{MB}$ onto the pristine biochars are also shown in Fig. 4. The sorption of MB differed greatly from that of $\mathrm{Pb}(\mathrm{II}), \mathrm{Zn}$ (II), and $\mathrm{Cd}(\mathrm{II})$ (Fig. 4). Fig. 4 showed the similar adsorption capacities of CB600, CB450, and $\mathrm{CB} 300$ for $\mathrm{MB}$, so the adsorption mechanism of $\mathrm{MB}$ was different from that of the heavy metal ions.

For better understanding the sorption process, the Langmuir and Freundlich models were used to fit experimental data (Table 2). All Langmuir model coefficients $(>0.97)$ were higher than Freundlich model coefficients, suggesting a better fitting with the Langmuir model. The Langmuir maximum sorption capacity of
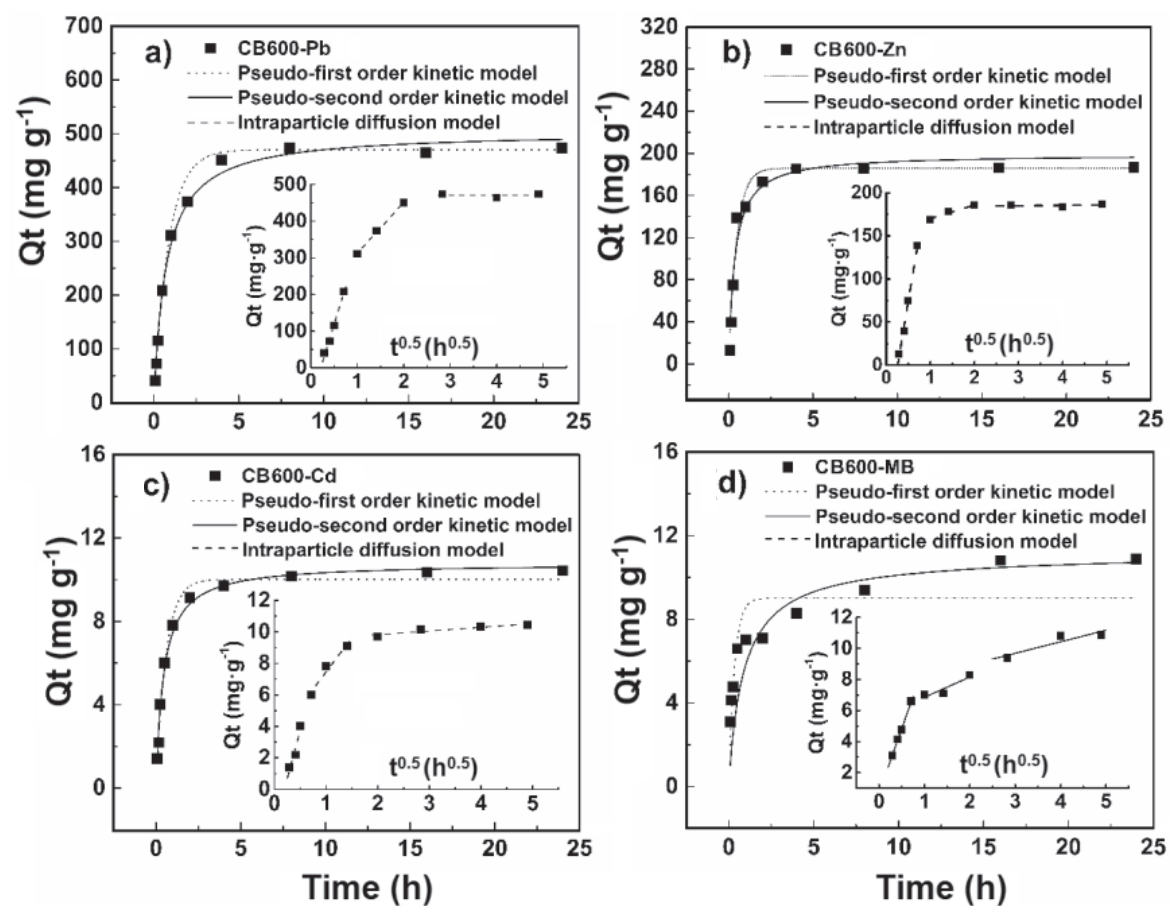

Fig. 5. Sorption kinetics of $\mathrm{Pb}(\mathrm{II}) \mathrm{a}), \mathrm{Zn}(\mathrm{II}) \mathrm{b}), \mathrm{Cd}(\mathrm{II}) \mathrm{c}$ ), and methylene blue d) onto CB600. 
Table 3. Kinetic model parameters for $\mathrm{Pb}(\mathrm{II}), \mathrm{Zn}(\mathrm{II}), \mathrm{Cd}(\mathrm{II})$, and MB sorption onto CB600.

\begin{tabular}{|c|c|c|c|c|c|c|c|c|c|c|}
\hline & \multirow[t]{2}{*}{$q_{e, e x p}$} & \multicolumn{3}{|c|}{$\begin{array}{c}\text { Pseudo first-order } \\
1 / q_{t}=1 / q_{e}+k_{1} /\left(q_{e} t\right)\end{array}$} & \multicolumn{3}{|c|}{$\begin{array}{c}\text { Pseudo second-order } \\
t / q_{t}=1 /\left[\left(q_{e}\right)^{2} \times k_{2}\right]+t / q_{e}\end{array}$} & \multicolumn{3}{|c|}{$\begin{array}{l}\text { Intraparticle diffusion } \\
q_{t}=K_{p} \times t^{0.5}+C\end{array}$} \\
\hline & & $\mathrm{Q}_{\mathrm{e}, \mathrm{cal}}$ & $\mathrm{k}_{1}$ & $\mathrm{R}^{2}$ & $\mathrm{Q}_{\mathrm{e}, \mathrm{cal}}$ & $\mathrm{k}_{2}$ & $\mathrm{R}^{2}$ & $\mathrm{~K}_{\mathrm{p}}$ & $\mathrm{C}$ & $R^{2}$ \\
\hline $\mathrm{Pb}(\mathrm{II})$ & 484 & 470 & 1.15 & 0.996 & 489 & 3.03 & 0.999 & 409 & -85.8 & 0.989 \\
\hline $\mathrm{Zn}(\mathrm{II})$ & 187 & 185 & 2.13 & 0.975 & 190 & 13.7 & 0.998 & 306 & -79.4 & 0.994 \\
\hline $\mathrm{Cd}(\mathrm{II})$ & 10.4 & 10.0 & 1.70 & 0.987 & 10.6 & 21.6 & 0.999 & 12.1 & -12.3 & 0.910 \\
\hline MB & 10.8 & 9.01 & 3.00 & 0.681 & 11.1 & 0.109 & 0.996 & 8.32 & 0.683 & 0.998 \\
\hline
\end{tabular}

$q_{e, e x p}:$ experimental equilibrium adsorption capacity $\left(\mathrm{mg} \mathrm{g}^{-1}\right), q_{e, c a l}$ : calculated equilibrium adsorption capacity $\left(\mathrm{mg} \mathrm{g}^{-1}\right), k_{l}: \mathrm{pseudo}$ first-order apparent adsorption rate constants $\left(\mathrm{h}^{-1}\right), k_{2}$ : pseudo second-order apparent adsorption rate constants $\left(\mathrm{mg} \mathrm{mg}^{-1} \mathrm{~h}^{-1}\right), K_{p}$ : intraparticle diffusion rate constants $\left(\mathrm{mg} \mathrm{g} \mathrm{h}^{-0.5}\right), C$ : constant $\left(\mathrm{mg} \mathrm{g}^{-1}\right)$.

CB600 was $458 \mathrm{mg} \cdot \mathrm{g}^{-1}$ for $\mathrm{Pb}(\mathrm{II}), 146 \mathrm{mg} \cdot \mathrm{g}^{-1}$ for $\mathrm{Zn}(\mathrm{II})$,

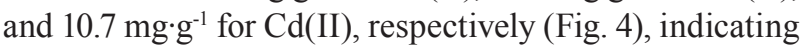
the elemental dependent. The sorption capacities of these heavy metal ions for CB600 were much higher than those for other carbon-based sorbents, including activated carbon reported in the literature [25-28]. So the waste corrugated-paper biochars can be used as an effective sorbent for the removal of heavy metal ions from aqueous solutions.

\section{Sorption Kinetics}

Adsorption kinetics of metals from CB600, which had maximum adsorption capacity for $\mathrm{Pb}(\mathrm{II}), \mathrm{Zn}$ (II), $\mathrm{Cd}(\mathrm{II})$, and $\mathrm{MB}$ among the 3 biochars, are shown in Fig. 5. Sorption amount of the 4 sorbates increased rapidly with contact time in the first 2 hours and then the increase of the adsorption amount slowed down. The sorption of the sorbates reached equilibrium in $5 \mathrm{~h}$ except for $\mathrm{MB}$, which needed about $10 \mathrm{~h}$. Pseudo first-order and pseudo second-order models, and the intraparticle diffusion model were used to fit the adsorption data and the parameters are listed in Table 3. The calculated equilibrium sorption capacities $\left(q_{e, c a l}\right)$ by pseudo second-

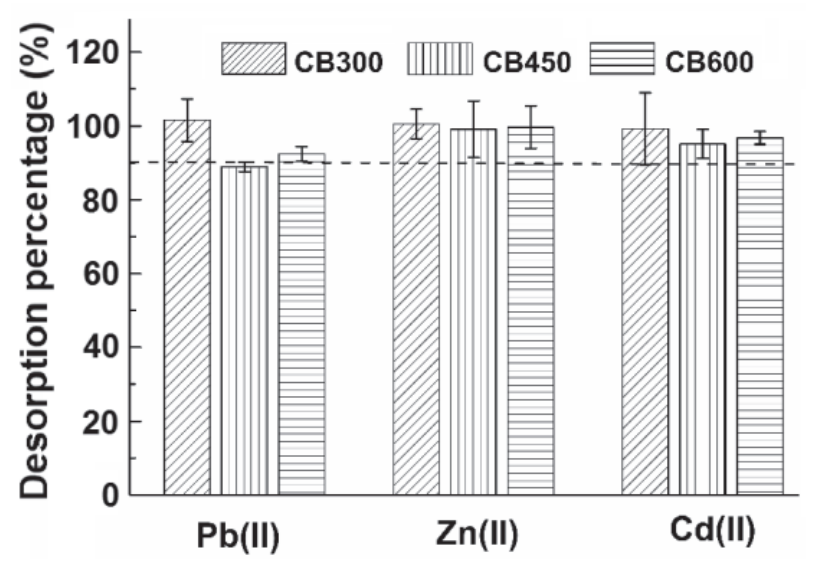

Fig. 6. Desorption of $\mathrm{Pb}(\mathrm{II}), \mathrm{Zn}(\mathrm{II})$, and $\mathrm{Cd}(\mathrm{II})$ from the metalladened biochars by $1 \mathrm{M} \mathrm{HNO}_{3}$. order of $\mathrm{Pb}(\mathrm{II}), \mathrm{Zn}(\mathrm{II}), \mathrm{Cd}(\mathrm{II})$, and MB were 489, 190, 10.6 , and $11.1 \mathrm{mg} \mathrm{g}^{-1}$, respectively, which were closer to the experimental $q_{e}$ values $\left(q_{e, e x p}\right)$. The correlation coefficient values $\left(R^{2}\right)$ of the pseudo second-order model were higher than that of the pseudo first-order model. These suggested that the pseudo second-order model provided a better fit for $\mathrm{Pb}(\mathrm{II}), \mathrm{Zn}(\mathrm{II}), \mathrm{Cd}(\mathrm{II})$, and $\mathrm{MB}$ adsorption than the pseudo first-order model (Fig. 5). Moreover, liner fitting results by intraparticle diffusion model were also shown in Fig. 5 and Table 3. It is reported that the initial straight line passing through the origin represented the external mass transfer region or surface adsorption [29]. Fig. 5 showed that the linear plot did not pass through the origin, which indicated that the intraparticle diffusion was not the only rate controlling step, and that boundary layer diffusion was involved. Therefore, $\mathrm{Pb}(\mathrm{II}), \mathrm{Zn}(\mathrm{II})$, $\mathrm{Cd}(\mathrm{II})$, and $\mathrm{MB}$ adsorption onto CB600 might occur by a multi-step adsorption process. This is similar to previous reports [29].

$$
\text { Desorption of } \mathrm{Pb}(\mathrm{II}), \mathrm{Zn}(\mathrm{II}) \text {, and } \mathrm{Cd}(\mathrm{II})
$$

Desorption rates of $\mathrm{Pb}(\mathrm{II}), \mathrm{Zn}(\mathrm{II})$, and $\mathrm{Cd}(\mathrm{II})$ from the metal-laden biochars are presented in Fig. 6. We found that more than $90 \%$ of absorbed $\mathrm{Pb}(\mathrm{II}), \mathrm{Zn}(\mathrm{II})$, and $\mathrm{Cd}(\mathrm{II})$ could be desorbed from the biochars using $1 \mathrm{M}$ $\mathrm{HNO}_{3}$, which suggested that $\mathrm{Pb}$ (II), $\mathrm{Zn}$ (II), and $\mathrm{Cd}(\mathrm{II})$ could be recycled well by immersing the metal-laden biochars in $1 \mathrm{M} \mathrm{HNO}_{3}$ solution.

\section{Conclusions}

Biochars were derived from waste corrugated-paper through slow pyrolysis under 300,450 , and $600^{\circ} \mathrm{C}$. The basic physicochemical properties and sorption performance of the resultant biochars were influenced greatly by the pyrolysis temperature. Biochar obtained at high pyrolysis temperature (CB600) exhibited high specific surface area and high mineral contents. Moreover, high-temperature biochar $\left(600^{\circ} \mathrm{C}\right)$ showed high removal of lead, zinc, and cadmium from aqueous solutions than low-temperature biochars did (300 
and $\left.450^{\circ} \mathrm{C}\right)$. The sorption of $\mathrm{Pb}(\mathrm{II})$ or $\mathrm{Zn}(\mathrm{II})$ onto the high-temperature biochars (CB600) was mainly controlled by a chemical precipitation mechanism while the sorption of MB contributed to electrostatic adsorption. Finally, dilute acid extraction successfully recovered the sorbed heavy metal from the exhausted sorbent. In a word, simple preparation and high removal efficiency of heavy metal ions make the waste corrugated-paper biochars promising cost-effective sorbents for wastewater treatment and it is helpful in developing novel recovery methods for waste corrugated cardboard boxes.

\section{Acknowledgements}

Our work was partly supported by the National Natural Science Fund of China (No. 21677075) and the Culture Project of International Cooperation and Exchange of Nanjing Tech University.

\section{References}

1. PIVNENKO K., ERIKSSON E., ASTRUP T.F. Waste paper for recycling: Overview and identification of potentially critical substances. Waste Manage 45, 134, 2015.

2. ADHIKARI C.R., PARAJULI D., INOUE K., OHTO K., KAWAKITA H., HARADA H. Recovery of precious metals by using chemically modified waste paper. New J Chem 32, 1634, 2008.

3. KALPANA D., CHO S.H., LEE S.B., LEE Y.S., MISRA R., RENGANATHAN N.G. Recycled waste paper - A new source of raw material for electric double-layer capacitors. J Power Sources 190, 587, 2009.

4. MA Y., HUMMEL M., MAATTANEN M., SARKILAHTI A., HARLIN A., SIXTA H. Upcycling of waste paper and cardboard to textiles. Green Chem 18, 858, 2016.

5. GHORBEL L., ROUISSI T., BRAR S.K., LOPEZGONZALEZ D., RAMIREZ A.A., GODBOUT S. Valueadded performance of processed cardboard and farm breeding compost by pyrolysis. Waste Manage 38, 164, 2015.

6. AZIMI A., AZARI A., REZAKAZEMI M., ANSARPOUR M. Removal of heavy metals from industrial wastewaters: A review. Chembioeng Rev 4, 37, 2017.

7. MATOVIC D. Biochar as a viable carbon sequestration option: Global and Canadian perspective. Energy 36, 2011, 2011.

8. SOHI S.P., KRULL E., LOPEZ-CAPEL E., BOL R. A review of biochar and its use and function in soil. In Sparks D.L. (ed.): Advances in agronomy, Vol. 105, Burlington: Academic Press, 2010, 47, 2010.

9. MAYER Z.A., ELTOM Y., STENNETT D., SCHRODER E., APFELBACHER A., HORNUNG A. Characterization of engineered biochar for soil management. Environ Prog Sustain 33, 490, 2014.

10. DING Z., HU X., WAN Y., WANG S., GAO B. Removal of lead, copper, cadmium, zinc, and nickel from aqueous solutions by alkali-modified biochar: Batch and column tests. J Ind Eng Chem 33, 239, 2016.

11. INYANG M.I., GAO B., YAO Y., XUE Y.W., ZIMMERMAN A., MOSA A., PULLAMMANAPPALLIL P., OK Y.S., CAO X.D. A review of biochar as a low-cost adsorbent for aqueous heavy metal removal. Crit Rev Env Sci Tec 46, 406, 2016.

12. AHMED M.B., ZHOU J.L., NGO H.H., GUO W., CHEN $\mathrm{M}$. Progress in the preparation and application of modified biochar for improved contaminant removal from water and wastewater. Bioresource Technol 214, 836, 2016.

13. MOHAN D., SARSWAT A., OK Y.S., PITTMAN C.U. Organic and inorganic contaminants removal from water with biochar, a renewable, low cost and sustainable adsorbent - A critical review. Bioresource Technol 160, 191, 2014.

14. MICHALEKOVA-RICHVEISOVA B., FRISTAK V., PIPISKA M., DURISKA L., MORENO-JIMENEZ E., SOJA G. Iron-impregnated biochars as effective phosphate sorption materials. Environ Sci Pollut R 24, 463, 2017.

15. HU X., DING Z.H., ZIMMERMAN A.R., WANG S.S., GAO B. Batch and column sorption of arsenic onto ironimpregnated biochar synthesized through hydrolysis. Water Res 68, 206, 2015.

16. XU X., HU X., DING Z., CHEN Y., GAO B. Waste-artpaper biochar as an effective sorbent for recovery of aqueous $\mathrm{Pb}$ (II) into value-added $\mathrm{PbO}$ nanoparticles. Chem Eng J 308, 863, 2017.

17. FARIA P.C.C., ÓRF O J.J.M., PEREIRA M.F.R. Adsorption of anionic and cationic dyes on activated carbons with different surface chemistries. Water Res $\mathbf{3 8}$, 2043, 2004.

18. BOGUSZ A., OLESZCZUK P., DOBROWOLSKI R. Application of laboratory prepared and commercially available biochars to adsorption of cadmium, copper and zinc ions from water. Bioresource Technol 196, 540, 2015.

19. KEILUWEIT M., NICO P.S., JOHNSON M.G., KLEBER M. Dynamic molecular structure of plant biomass-derived black carbon (biochar). Environ Sci Technol 44, 1247, 2010.

20. TAN X., LIU Y., ZENG G., XIN W., HU X., GU Y., YANG $Z$. Application of biochar for the removal of pollutants from aqueous solutions. Chemosphere 125, 70, 2015.

21. XU X., CAO X., ZHAO L. Comparison of rice huskand dairy manure-derived biochars for simultaneously removing heavy metals from aqueous solutions: Role of mineral components in biochars. Chemosphere 92, 955, 2013.

22. YAO Y., GAO B., INYANG M., ZIMMERMAN A.R., CAO X., PULLAMMANAPPALLIL P., YANG L. Biochar derived from anaerobically digested sugar beet tailings: Characterization and phosphate removal potential. Bioresource Technol 102, 6273, 2011.

23. TAN C., ZHANG Y., WANG H., LU W., ZHOU Z., ZHANG Y., REN L. Influence of pyrolysis temperature on characteristics and heavy metal adsorptive performance of biochar derived from municipal sewage sludge. Bioresource Technol 164C, 47, 2014.

24. YANG G., WANG Z., XIAN Q., SHEN F., SUN C., ZHANG Y., WU J. Effects of pyrolysis temperature on the physicochemical properties of biochar derived from vermicompost and its potential use as an environmental amendment. RSC Adv 5, 40117, 2015.

25. PYRZYNSKA K. Sorption of Cd(II) onto carbon-based materials-a comparative study. Microchim Acta 169, 7, 2010.

26. DING W., DONG X., IME I.M., GAO B., MA L.Q. Pyrolytic temperatures impact lead sorption mechanisms by bagasse biochars. Chemosphere 105, 68. Chemosphere 105, 68, 2014. 
27. JIANG S., HUANG L., NGUYEN T.A.H., OK Y.S., RUDOLPH V., YANG H., ZHANG D. Copper and zinc adsorption by softwood and hardwood biochars under elevated sulphate-induced salinity and acidic $\mathrm{pH}$ conditions. Chemosphere 142, 64, 2016.

28. DING Z., HU X., WU H. Multiple characterization for mechanistic insights of $\mathrm{Pb}(\mathrm{II})$ sorption onto biochars derived from herbaceous plant, biosolid, and livestock waste. Bioresources 12, 6763, 2017.

29. LIU N., CHARRUA A.B., WENG C.H., YUAN X., DING F. Characterization of biochars derived from agriculture wastes and their adsorptive removal of atrazine from aqueous solution: A comparative study. Bioresource Technol 198, 55, 2015. 
